\title{
Women Empowerment through Shgs
}

\author{
Roshni Rawat \\ Research Scholar In D.A.V College (School Of Commerce) Dehradun \\ Affiliated To HNB Garhwal University, Srinagar (Uttarakhand)
}

\begin{abstract}
Microfinance Has Enabled The Active Poor To Have Access To All Financial Products Which Has Never Been Utilized In The Traditional Financial System. The Research Paper Sheds A Light On The Role Of Microfinance In Women Empowerment Which Is Considered As One Of Indispensable Part Of Inclusive Growth Of The Economy. This Paper Explain The Role Of Shgs In Women Empowerment By Raising Their SocioEconomic And Political Status In Derabassi Block Of Mohali (S.A.S Nagar) District In Punjab. Economic, Social As Well As Political Status Of Women Taken Into Consideration As A Tool For Women Empowerment. The Study Has Been Undertaken By Collecting The Primary Data From 200 Shgs Members. The Social Impact Of Self-Help Group On Women Is Compared With Economic And Political Impact Of Self-Help Groups On Women.
\end{abstract}

Key Words: Social Empowerment, Economic Empowerment, Political Empowerment,Self-Help Groups.

\section{Introduction}

The Well Being Of People Is The Ultimate Goal Of All Development Efforts And The Basic Quest Of Human Endeavor Is Always To Seek A Better Quality Of Life And Better Quality Of Life Can Effectively Improved Only By Raising The Standard Of Living Of The People And Women Empowerment In Particular Is Very Fundamental In Achieving This Goal.

In India Women Accorded As Deties In Mythology And Personified Tribute Paid To Them As In Historical Monuments But The Ground Realities Is Opposite. Our Country Is Male Dominated Society In Which Women Share Is Negligible.The Indian Constitution Guarantees That There Shall Be No Discrimination On The Grounds Of Gender. In Reality, However, Rural Women Have Harder Lives And Are Often Discriminated Against With Regard To Land And Property Rights, And In Access To Medical Facilities And Rural Finance. Women Undertake The More Onerous Tasks Involved In The Day-To-Day Running Of Households, Including The Collection Of Fuelwood For Cooking And The Fetching Of Drinking Water, And Their Nutritional Status And Literacy Rates Are Lower Than Those Of Men. They Also Command Lower Wages As Labour: As Rural Non-Agricultural Labourers, Women Earn 44 Rupees Per Day Compared To 67 Rupees For Men By United Nations Report(2001) 'Women In India - How Free? How Equal?'. This Volunerable Situation Of Women Can Reduce Through Self Help Groups. Shgs Are Small Groups Of Poor People Who Have Facilitated The Poor, Especially The Women To Overcome The Existing Constraints Faced By Poor For Availing Benefites Of Financial Products From Formal Financial Credit Institutions Without Collateral.

\section{Women Empowerment And Shgs}

Empowerment Is Not Essentially Political Alone; It Is A Process Having Personal,Economic, Social And Cultural Dimensions With Personal Empowerment Being Thecore Of The Empowerment Process. In Fact Political Empowerment Will Not Succeed Inthe Absence Of Economic And Social Empowerment. The Scheme Of Micro-Financing Throughshgs Create Empowerment Promoting Conditions For Women To Move From Positionsof Marginalisation Within Household Decision Making Process And Exclusion Withincommunity, To One Of Greater Centra. The Social Processes Of Micro Financing Programmes Strengthens Women's Self Esteem And Self -Confidence, Instill A Greater Sense Of Awareness Of Social And Politicalissues Leading To Increased Mobility And Reduced Traditional Seclusion Of Women.

Most Importantly Micro-Finance Programmes Enable Women To Contribute To Thehousehold Economy, Increasing Their Intra-Household Bargaining Power. Thus, Microfinancing Through Self-Help Groups Has Transferred The Real Economic Power In Thehands Of Women And Has Considerably Reduced Their Dependence On Men. But Thelack Of Education Often Comes In The Way And Many A Times They Had To Seek Helpfrom Their Husbands Or Any Other Educated Man/ Woman For Day-To-Day Work. Thepolitical As Well As Economic Empowerment Will Not Succeed In The Absence Ofwomen Education In Skills And Vocations They Require The Most.Key Instruments For Supporting Women's Empowerment Are Self-Help Groups, Whereby 10-20 Rural Women From The Same Village, Mostly Poor Women, Come Together To Contribute Two-Weekly Or Monthly Dues As Savings And Provide Group Loans To Their Members.Lity, 
Inclusion Of Voice.A Majority Of Microfinance Programmes Target Women With The Explicit Goal Ofempowering Them. There Are Varying Underlying Motivations For Pursuing Womenempowerment. Some Argue That Women Are Amongst The Poorest And The Mostvulnerable Of The Underprivileged And Thus Helping Them Should Be Priority.Whereas, Other Believe That Investing In Women's Capabilities Empowers The To Make Choices Which Is A Valuable Goal In Itself But It Also Contributes Togreater Economic Growth And Development. It Has Been Well-Documented That Anincrease In Women's Resources Results In The Well-Being Of The Family, Especiallychildren.

\section{Literature Review}

Sudan (2004) Reveled That Poverty And Deprivation Increase Gender Inequality, Which Favours A Policy For Empowerment Of Women By Increasing Their Access To Credit Through SHG's So As Enable Them To Acquire The Capability And Assets That Can Help Facilitate Realize Strategic Gender Needs The SHG's Can Be Built On Social Capital Of The Local Community Especially Women To Carry Out Thrift And Credit Activities To Initiate Micro-Income Generating Activities To Eke Out A Sustainable Livelihood.Forsen (1993), Empowerment Is Reflected In A Person's Capability Set. The 'Capability'of A Person Depends On A Variety Of Factors, Including Personal Characteristics And Socialarrangements. Empowerment Is The Capacity To Fulfill This Capability And Not Just Thechoice To Do So. Sen's View On Women's Empowerment Is Indicated In His Discussion Ofmeasurement Of Empowerment. According To Him, The Focus Should Be Oncertain Universally Valued Functionings, Which Relate To The Basic Fundamentals Ofsurvival And WellBeing Regardless Of Context. These Include Proper Nourishment, Goodhealth And Shelter. If There Are Systematic Gender Differences In These Very Basicfunctioning Achievements, They Can Be Taken As Evidence Of Inequalities In Theunderlying Capabilities, Rather Than As Differences In Preferences. Kabeer(2001), Hulme And Mosley(1997) The Predominant Image Of Empowerment In Development Is That Of Women Gaining (Material) Means To Empower Themselves As Individuals, And Putting This To The Service Of Their Families And Communities." This Is Primarily Because Empowerment Is Understood In Relation To Deliberate And Planned Interventions Such As Electoral Quotas, Education, Economic Empowerment Initiatives, Legislative Change And Non-Governmental Public Action.

\section{Objectives Of Study}

The Main Objective Of The Present Study Is To Analyse The Impact Of Microfinance Through Shgs On Economic Social And Political Empowerment Of Women In Derabassi Block Of Mohali District, Punjab But More Specifically Are Showed Below:-

- To Analyse The Impact Of Microfinance Through Shgs In Economic Empowerment Of Rural Women.

- To Study The Role Of Microfinance Through Shgs In Social Uplifment Of Rural Women.

- To Understand The Impact Of Microfinance Through Shgs In Political Empowerment Of Rural Women.

\section{Research Methodology}

The Present Study Was Purposive Sampling In Nature In Which 200 Members (Beneficiaries) Of Shgs Were Selected From Derabassi Block Of Mohali District, Punjab. The Data Was Collected By Both Primary And Secondary Source. The Primary Data Was Collected Through Preparing Questionnaire And Interviewing The Selected Members. The Questionnaire Was Designed In Such A Way Which Shows Economic Factors, Social Factors And Political Factors Which Get Affected By Microfinance Through Shgs. The Secondary Data Was Collected From Magazines, Books, Journals, And From Various Websites.

\section{Tools Used}

The Primary Data Collected Through Questionnaire Was Analysed With The Use Of Statistical Tools. The Descriptive Analysis Was Undertaken Using Absolute Percentages And Change In Percentages To Study The Impact Of Microfinance Through Shgs On Members In Both Pre-SHG And Post-SHG Situations. The Indices Of Social, Economic And Political Factors Are Also Calculated.

\section{Indices Of Social Economic And Political Indicators}

The Social Indicators Include Self-Confidence, Education Level, Domestic Violence, Communication Abilities, Sanitation Facilities Decision Making Power And Water Supply.The Economic Indicators Include Access To Easy Credit, Income Level, Expenditure, Saving And Repayment Status Of Loan. The Political Indicators Include Critical Political Consciousness, Knowledge Of Election Procedure, Awareness Of Forming Of Political Bodies Viz: Panchayat And Participation In Political Activities. 
The Different Indices Were Calculated As Follows:

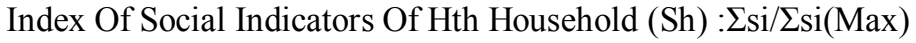

Index Of Economic Indicators Of Hth Household (Eh) : $\Sigma \mathrm{ej} / \Sigma \mathrm{ej}(\mathrm{Max})$

Index Of Political Indicators Of Hth Household (Ph) : $\Sigma \mathrm{pk} / \Sigma \mathrm{pk}($ Max)

Where, Si, Ej And Pk Represent Social, Economic And Political Indicators, Respectively.

\section{Findings and Analysis}

The Demographic Analysis Is Prerequisite Before Discussing Any Impact Of Shgs On Selected Members Which Includes Age Of Respondents, Poverty Level, Education Status, Caste Belonged To, Type Of Family, Occupation, Type And Size Of Land Holding And Purpose Of Joining The Group. Therefore The Collected Primary Data Reveled That Majority Of Members I.E. 65 Percent Of Selected Members Fall Under Age Group Of 25-34 Years, Followed By (19 Percent) 36-44 Years Of Members And 16 Percent Lie In Age Less Than 25 Years Of Age. The 82 Percent Members Comes Under BPL Families And Remaining In APL Families. The Caste Wise Distribution Of Members Shows That Maximum 50 Percent Members Belongs To Scs And Followed By 36 Percent Belongs To Bcs And Remaining All Belongs To General Caste Among Selected Members. The Results States That Approximately 45.7 Percent Of The Respondents Completed Their Primary Level Education, Followed By 32 Percent Completed Middle Level Education, 18.6 Percent Were Illiterate Means Did Not Get Any Formal Education But Can Read And Write Punjabi Language And All Other Were Belonged To Secondary And Sr. Secondary Level Of Education. The Marital Status Shows That 81.4 Percent Of The Respondents Were Married And All Other Fall Under Categories Of Single, Separated And Widow.

The Majority Of Selected Members Were In Joint Family (82 Percent) And Only 18 Percent In Nuclear Family. The Result Explains That 47.8 Percent Of Members Landless,34.6 Percent Had Marginal Land And Remaining All Were Holding Small Land And Those Holding Land Was Either Owned Or Leased One. The Occupation Data Shows That 38.7 Percent Of Respondents Were Self Employed, Followed By Livestock (92.2 Percent) And 18.5 Of Members Were Engaged In Agricultural Activities Remaining In Any Other Activities. The Purpose Of Loan Of Respondents Depicts That Maximum Loan Was Borrowed For Setting Up Small Enterprise Which Includes Both Agri-Bussiness And Non Agri-Business, In Order To Increase Their Income And Saving Level And Some Members Had Borrowed For Consumption Purpose. All The Major Family Decisions Were Taken Maximum I.E. 62 Percent Jointly And 19.8 Percent Decisions Were Taken By Husband Individually And Remaining By Head Of Family And Other Members. There Are 10-15 Members In Each Group And The Frequency Of Their Meeting Was Fortnightly, Weekly And Sometime Monthly But Data Explains That Majority Of Meeting Conducted Fortnightly Followed By Weekly And Monthly. The Collected Data Shows That Maximum I.E. 89 Percent Of Loan Borrowed From Cooperative Banks And Remaining From Commercial And Regional Rural Banks.

Pre And Post Shgs Impact On Social Lvariables

\begin{tabular}{|c|c|c|c|c|}
\hline Sr.No. & Social Variables & Before SHG & After SHG & $\begin{array}{l}\text { Percentage } \\
\text { Change }\end{array}$ \\
\hline 1. & Self Confidence & $76(38)$ & $176(88)$ & 131.5 \\
\hline 2. & $\begin{array}{l}\text { Education Level } \\
\text { Primary } \\
\text { Middle } \\
\text { Higher } \\
\text { Illiterate }\end{array}$ & $\begin{array}{l}92(45.7) \\
64(32) \\
42(21) \\
7(3.7)\end{array}$ & $\begin{array}{l}155(77.4) \\
130(65.2) \\
64(32) \\
2 \quad(0.9)\end{array}$ & $\begin{array}{l}68.4 \\
103 \\
\\
-71.4 \\
\end{array}$ \\
\hline 3. & $\begin{array}{l}\text { Domestic Violence } \\
\text { ( Of Husband And Others) }\end{array}$ & $134(67)$ & $36(18)$ & -73.2 \\
\hline 4. & Access To Medical Facilities & $70(35)$ & $158(79)$ & 125.7 \\
\hline 5. & $\begin{array}{l}\text { Communication Ability } \\
\text { (Free Talk) }\end{array}$ & $10(5)$ & $120(60)$ & 1100 \\
\hline 6. & Sanitation Facility & $52(25.8)$ & $150(74.9)$ & 188.5 \\
\hline 7. & $\begin{array}{l}\text { Decision Making In } \\
\text { Important Matters }\end{array}$ & $42(21)$ & $178(89)$ & 423.8 \\
\hline 8. & Water Facility & $96(48)$ & $170(85)$ & 77 \\
\hline
\end{tabular}

\section{Social Impact Of Shgs On Members}

Many Years Have Been Passed Since Independence Still The Rural Women Are Lacking Far Behind Even For Access Of Basic Amenities Of Life Such As Health, Sanitation And Education Etc. The Social Variables Included To Find The Impact Of Shgs Were Self-Confidence, Education Level, Domestic Violence, Access To Medical Facilities, Communication Abilities, Sanitation Facilities, Decision Making Power And Water Supply. 
Source: Primary Data, Parenthesis Shows Percentages. The Self Confidence Was Find Out Through The Data Collected Regarding Confidence In General As Well As Specifically Like Financial Constraints Of Family Treatment And In Helping The Neighbours. The Table Shows That 38 Percent Of Respondents Have Self Confidence Before SHG Whereas 88 Pernt Of Them Showed Their High Confidence During Post SHG Situation. Hence It Is Revel That There Was 131.5 Percent Increase In The Level Of Self Confidence Among Selected Women After Joining Shgs.

The Members Were Laying In Primary, Middle, Higher And Illiterate Situation And Level Of Literacy In All Primary, Middle And Higher Education Increased After Joining SHG By Selected Members And Illiteracy Level Decreased By 71.4 Percent After Becoming A Member Of Group.

Violence Against Women Is Historically Unequal Power Relations Between Men And Women, Which Have Led To Domination And Discrimination Against Women. The Data Collected Explains That Before Joining SHG The More Women I.E 67 Percent Selected Members Were Facing Violence From Their Husbands And Other Members Of House And Society But Now After Joining Groups They Started Protesting Against Them And So The Violence Against Them Reduce To 18 Percent And Therefor The Overall Decreased In Violence Was 73.2 Percent.

Access To Medical Facilities Is One Of Basic Requirement For Survival Of Human But Still Indian Women Are Lacking Far Behind To Reach All These. The 35 Percent Of Selected Members Have Access To Medical Facilities During Pre SHG And 79 Percent Of Members In Post SHG Situation. Hence, The Members Increase 125.7 Percent To Access To All Medical Facilities.

Communication Means Exchange Of Ideas And Views Freely. The Table Shows That Most Of The Selected Members Were Hesitate To Talk Freely And Talk Only When Asked In Pre SHG Situation I.E. Only 5 Percent But In Post SHG Situation 60 Percent Of Members Started Talking Freely And Presenting Their Views Effectively In Front Of Others And Therefor Communication Skill Increase Drastically 1100 Percent After Be A Part Of SHG.

The Data Collected Shows That Only Few 25.8 Percent Of Selected Women Had Better Access To Sanitation Facilities In Pre SHG Situation And There Was Found Considerable Amount Of Incrpease I.E. 188.5 Percent Women Members Have Access To Sanitation Facilities After Joining Group.

The Rural Women Are Lacking Far Behind Men And Other Women In Important Decision Making Power Relating To Children Education And Family Planning Etc As Before Joining SHG Only 21 Percent Of Selected Women Members Have Power To Take Decisions But In Post SHG Situation 89 Percent Of Members Were Started Taking Important Decisions.

It Was Also Cited That Water Supply Service Was Availed Around Only To 48 Percent Of Members Before Becoming Member Of Group And 89 Percent After Becoming Member Of Group, The Water Supply Were Availed In Post SHG Situation From Concern Department Of Government Of Punjab . Hence, 37 Percent Increase In Members Is Showed From Table.

\section{Social Impact Indicators Index Score}

The Social Impact Of Self Help Groups On Rural Women Measured From Various Social Variables Such As Self Confidence, Communication Abilities, Decision Making Power, Accessibility Of Medical Facilities, Sanitation Facilities, Education Level, Domestic Violence And Water Supply And So I Framed The Social Index Score Based On Simple Percent Analysis. In Which The Social Index Score Is Between 0-9 It Means The Social Impact Of Microfinance Through Shgs On Rural Women Is Low. Similarly, If The Social Index Score Is Between 10-19 It Denotes That Social Impact Is Medium And If The Index Score Is Between 2029 It Means The Social Impact Is High And At Last When Score Of Index Above 29 It Denotes The Social Impact Is Very High.

Social Impact Index Score

\begin{tabular}{|l|l|l|l|}
\hline Index Score & $\begin{array}{l}\text { Level Of Social } \\
\text { Standard }\end{array}$ & Before SHG & After SHG \\
\hline $0-9$ & Low & $124(62)$ & $30(15)$ \\
\hline $10-19$ & Medium & $16(8)$ & $20(10)$ \\
\hline $20-29$ & High & $28(14)$ & $36(18)$ \\
\hline Above 29 & $32(16)$ & $114(57)$ \\
\hline \multicolumn{2}{|l|}{ TOTAL } & $200(100)$ & $200(100)$ \\
\hline
\end{tabular}

Source: Primary Data, Parenthesis Indicate The Percentage The Data Explained Through Table Shown Above Infers That In Low Level Of Social Standards The Before SHG Members Were 62 Percent (124 Score) And In After SHG Members Were Decreased To 30 Percent (15 Score) And The Level Of Standard Is Increased In Medium Level Of Social Standards From 8 Percent (16 Score) To 10 Percent After Joining SHG. The Members Percent Was 14 Percent (28 Score) In Pre SHG And Which Increased To 18 Percent (36 Score) In Post SHG 
Situation In High Level Of Social Standards And Similarly In Case Of Very High Level There Was Increase In Members From 16 Percent (32 Score) Before Joining SHG To 57 Percent (114 Score) After Joining The SHG. Hence, All These Level Of Social Standard Shows That There Is Increase In Social Status Of Rural Women From Pre To Post SHG Situation.

\section{Economic Impact Of Shgs On Members}

The Microfinance Was Originated To Improve The Financial Structure Of Poor And Deprived Society Mainly Rural Women. The Shgs Was Formed As Supply Mechanism To Assist The Poor Rural Women As They Are Facing Financial Constraints. The Economic Variables Which Were Taken Into Consideration Were Such As Access To Easy Credit, Income Level, Expenditure, Saving And Repayment Status Of Loan.

Pre And Post Shg Impact On Economic Variables

\begin{tabular}{|c|l|l|l|l|}
\hline Sr. No. & Economic Variables & Before SHG & After SHG & Percentage Change \\
\hline 1 & Access To Easy Credit & $40(20)$ & $200(100)$ & 400 \\
\hline 2. & Increase In Income Level & $\begin{array}{l}82 \\
(41)\end{array}$ & $164(82)$ & 100 \\
\hline 3. & $\begin{array}{l}\text { Increase In Expenditure } \\
\text { Structure }\end{array}$ & $\begin{array}{l}64 \\
(32)\end{array}$ & $178(89)$ & 178 \\
\hline 4. & Better Saving Status & $102(51)$ & $130(65)$ & 27.5 \\
\hline 5. & Repayment Status & $156(78)$ & $196(98)$ & 25.6 \\
\hline
\end{tabular}

Source: Primary Data, Parenthesis Indicate The Percentage

The Results Explained That The Accessibility Of Easy Credit Was Only To 20 Percent Members Before Joining SHG And In Post SHG It Was To All Members And Thus It Shows 400 Percent Increase In Accessibility Of Easy Credit Whose Main Reason Found Was Credit Without Collateral.

As The Results Reveled That The Level Of Income Increase Only Of 41 Percent Members In Pre SHG As Having Lack Of Finance To Start Any Work But In Post SHG Situation The Level Of Income Increase Considerably I.E. Now 82 Percent Of Members Income Raise. Therefore, There Was 100 Percent Increase In Members Whose Income Increases After Joining SHG.

As The Level Of Expenditure To Increase The Standard Of Living Before Joining The Group Was 28 Percent Of Members But In Post SHG It Becomes 82 Percent Of Members. Hence, Show 178 Percent Increase In Members Whose Expenditure Level Increased As By Spending Their Earning To Increase Their Quality Of Life.

The Most Of The Selected Women Joined The SHG In Order To Increase Their Saving Level. As Table Shows That A Good Number Of Members As 53 Percent Of Members Were Saving Sufficiently In Pre SHG Situation As Don't Aware About Quality Of Life, Even The Percent Of Member Increase To 71 Percent In Post SHG Situation But That Was Due To Increase In Level Of Income After Joining SHG.

The Selected Members Were Borrowing From Relatives, Friends And Moneylenders In Pre SHG Situation Then 78 Percent Of Members Were Repaying After A Long Period Of Time Due To Lack Of Sufficient Earning And High Rate Of Interest Charged By Them But In Post SHG Situation 98 Percent Of Members Were Repaying Their Borrowing As In Microfinance Flexible Time And Low Rate Of Interest Charged By SHG.

\section{Economic Impact Indicators Index Score}

The Economic Variables Taken To Find The Impact Of Microfinance Through Self Help Groups Are Income, Access To Easy Credit, Expenditure, Saving And Repayment Status And For Them Economic Index Is Formulated In Which Scores Are Calculated On The Basis Of Simple Percentage Analysis Where The Index Score Of 0-9 Is For Low Level Of Economic Standards, 10-19 For Medium Level, 20-29 For High Level And Above 29 Index Score For Very High Level Of Economic Standard.

Economic Impact Index Score

\begin{tabular}{|l|l|l|l|}
\hline Index Score & $\begin{array}{l}\text { Level Of Economic } \\
\text { Standard }\end{array}$ & Before SHG & After SHG \\
\hline $0-9$ & Low & $106(53)$ & $56(28)$ \\
\hline $10-19$ & Medium & $44(22)$ & $34(17)$ \\
\hline $20-29$ & High & $36(18)$ & $42(21)$ \\
\hline Above 29 & Very High & $14(7)$ & $68(34)$ \\
\hline \multicolumn{2}{|l|}{ TOTAL } & $200(100)$ & $200(100)$ \\
\hline
\end{tabular}

Source: Primary Data, Parenthesis Indicate The Percentage

The Table Shown Above States That The Rural Women Decrease In Low Level Of Economic Standard From 53 Percent Scored 106 In Pre SHG Situation To 28 Percent Scored 56 In Post SHG Situation. Similarly In 
Medium Level Standard It Show Decrease From 22 Percent Scored 44 To 17 Percent Scored 34 During Pre To Post SHG Situation. But The Situation Get Reversed In High And Very High Level Of Economic Standards, In High Level Increased From 18 Percent Scored 36 To 21 Percent Scored 42 From Non -Joining SHG To Joining SHG And In Very High Level Also The Percent Increased From 7(14 Score) To 34 Percent(68 Score). Therefore The Overall Results Shows Increase In Economic Status Of Rural Women In Post SHG Situation.

\section{Political Impact Of Shgs On Members}

The Government Of India Initiated Many Steps In Increasing The Political Role Of Women But All Are Abortive In Real Ground Of Rural Areas But Now Some Steps Were Taken Through Shgs For Political Empowerment Of Women Were Seen Positive. The Political Variables Were Taken For Study Was Critical Political Consciousness, Knowledge Of Political Procedure, Awareness Of Form Of Political Bodies Viz. Panchayat, Participation In Political Activities.

Pre And Post SHG Impact On Political Variables Of Members

\begin{tabular}{|l|l|c|c|c|}
\hline Sr.No. & Political Variables & Before SHG & After Shgs & $\begin{array}{l}\text { Percentage } \\
\text { Change }\end{array}$ \\
\hline 1. & Critical Political Consciousness & $24(12)$ & $156(78)$ & 550 \\
\hline 2. & Knowledge Of Electoral Procedure & $12(6)$ & $54(27)$ & 350 \\
\hline 3. & $\begin{array}{l}\text { Awareness Of Formation Of Political Bodies } \\
\text { Viz. Panchayat }\end{array}$ & $76(38)$ & $162(81)$ & 113 \\
\hline 4. & Participation In Political Activities & $4(2)$ & $28(14)$ & 600 \\
\hline
\end{tabular}

Source: Primary Data, Parenthesis Indicate The Percentage

The Table Shows That Only 12 Percent Of Members Were Conscious Regarding Political Activities During Pre SHG Situation But The Members Consciousness Increase By 550 Percent Of Member In Post SHG Situation.

The Members Were Sufficiently Lacking Regarding The Critical Procedure Followed In Political Activities I.E. Only 6 Percent Of Members Have Knowledge Regarding The Political Procedure But After Joining SHG The 27 Percent Of Women Acquaint Themselves Regarding The Procedure Followed In Political Participation. Therefore Shows 350 Percent Increase In Members After Joining SHG.

The Data Collected Explains The Sufficient I.E. 38 Percent Of Women Were Already Aware Of Panchayat Before Joining SHG But Their Percent Increase To 81 Percent After Joining SHG And Shows Increase Of 113 Percent Members After Becoming A Part Of SHG.

Only Few 2 Percent Of Members Were Participating In Political Activities Due To Lack Of Knowledge And Self Confidence In Pre SHG Situation Which Rose To 14 Percent Of Members In Post SHG Situation. Hence Around 600 Percent Of Members Participation Increase After Joining SHG.

\section{Political Impact Indicators Index Score}

Politically Rural Women's Status Is Very Low Still Now. The Variables Taken For Political Empowerment Were Critical Political Consciousness, Knowledge Of Political Procedure, Awareness Of Formation Of Political Bodies As Panchayat And Participation In Political Bodies And Now Political Index Score Is Framed Based On Simple Calculation Through Percentage Analysis. Similarly Like Social And Economic Index Score In This Index Also Low Level Is From 0-9, Medium 10-19, High 20-29 And Very High Is Above 29 Index Score.

Political Impact Index Score

\begin{tabular}{|l|l|l|l|}
\hline Index Score & $\begin{array}{l}\text { Level Of Political } \\
\text { Standard }\end{array}$ & Before SHG & After SHG \\
\hline $0-9$ & Low & $176(86)$ & $96(48)$ \\
\hline $10-19$ & Medium & $16(8)$ & $64(32)$ \\
\hline $20-29$ & High & $6(3)$ & $14(28)$ \\
\hline Above 29 & $2(1)$ & $12(6)$ \\
\hline \multicolumn{2}{|l|}{ TOTAL } & $200(100)$ & $200(100)$ \\
\hline
\end{tabular}

Source: Primary Data, Parenthesis Indicate The Percentage

The Table Expresses The Political Impact Index Score, In Which The Low Level Of Standard Shows 86 Percent Scored 176 In Pre SHG Situation And Decreased To 48 Percent Scored 96 In Post SHG Situation. In Medium Level Of Political Standard There Was Increase From 8 Percent (16 Score) To 32 Percent (64score) During The Pre To Post SHG Situation. In Case Of High Standard In Pre SHG It Was 3 Percent (6score) And Increased To 28 Percent (14score) In Post SHG Situation. The Very High Level Shows 1 Percent (2score) In Pre And Increase To 6 Percent (12score) In Post SHG Situation. Finally Overall Political Index Score Shows That After Joining SHG Rural Women Become More Politically Empowerement. 


\section{Limitation Of The Study}

The Main Limitation Of The Study Was Time, Cost And Availability Of Information .The Limited Area And Lesser Amount Of Interaction Was The Another Limitation Of Study.

\section{Conclusion Of The Study}

The Actual Development Of India Lives In Its Villages Where The Deprived And Voulenerable Lacking Almost All The Basic Necessities And Rural Women Are One Of The Important Part Of It. At The End Of Ninth Five Year Plan Various Rural Schemes Were Implemented To Reduce Poverty And

To Promote Gainful Self Employment. But The More Attractive Scheme With Less Effort Is "Self Help Group". It Is A Weapon To Reduce Poverty And Improve The Rural Development Especially Women (Gowharjhan\&Saradha 2010). Various Initiatives Are Taken By Government To Empower Rural Women Through Microfinance. The Result Shows That Self Help Groups Are

Positively Influencing The Social, Economic And Political Aspects For Rural Women But The Social Uplifment Was Maximum Through These Programmes As Compared To Economic And Political Empowerment.

\section{Refrencecs}

[1]. Ritu Jain (2003), “Socio-Economic Impact Through Self Help Groups”, Yojana, Vol.47, No.7, Pp.11-12.

[2]. Cheston S And Kuhn L, 2002: 'Empowering Women Through Microfinance', Draft,

[3]. Opportunity International.

[4]. Hashemi SM, Schuler SR And Riley AP, 1996: 'Rural Credit Programmes And Women's

[5]. Empowerment In Bangladesh', World Development, Vol. 24, No. 4, Pp. 635-653.

[6]. Nussbaum, M., 2000: Women And Human Development: The Capabilities Approach.

[7]. Cambridge University Press: Cambridge.

[8]. Puhazhendi, V. And Satyasai, K.J.S., 2001: Economic And Social Empowerment Of Rural

[9]. Poorthrough Shgs, Indian Journal Of Agricultural Economics, Vol. 56. No. 3. 